\title{
Fiscal policy and incentives for development of the Soviet planned economy in the industrialization period
}

\author{
S. K. Sodnomova ${ }^{1, a}$, Yu. V. Leontyeva ${ }^{2, b}$ \\ ${ }^{1}$ Baikal State University, Irkutsk, Russian Federation \\ 2 Ural Federal University, Ekaterinburg, Russian Federation \\ a (iD) 0000-0002-5898-0537 \\ ${ }^{b}$ (D) $\underline{0000-0003-4676-9926}$
}

\begin{abstract}
The article is aimed at studying the Soviet fiscal policy and its effects on the country's economic development in 1926-1940. We used a historical and logical method to research the effectiveness of the two instruments of taxation - the turnover tax and tax charges on profits - and their role in the impressive achievements of the Soviet economy. To analyze and compare the data we used the key indicators of economic development and tax collection for 1926-1940. The results of the analysis have confirmed our hypothesis that the turnover tax and tax charges on profits along with price regulation and planned economy led to the formation of a costeffective economic model in the USSR. We have shown that this model ensured constant reduction of production costs, accelerated growth of the urban population and unprecedented expansion of heavy industry. Radical simplification of the tax system, which was a part of the 1930s reform, not only had a considerable fiscal effect but also affected social development. The turnover tax and tax charges on profits allowed the government to mobilize considerable resources for investment to stimulate growth in production of heavy industry at a rate of $10-16 \%$ a year, which created a multiplier effect in the whole economy. However, financial resources were mobilized at the expense of consumers, since higher taxes were mainly imposed on enterprises of light industry and food industry. This led to "commodity hunger", the introduction of ration cards, and strict administration. It is concluded that the distinctive feature of the Soviet fiscal policy was its complex nature and subordination to the single goal of the country's industrialization.
\end{abstract}

\section{KEYWORDS}

turnover tax, tax charges on profit, industrialization, Soviet planned economy, costeffective economy

JEL N4, E62

УДК 336.02

Оригинальная статья

\section{Практика использования специфических налоговых инструментов в период индустриализации плановой экономики СССР}

\author{
С. К. Содномова ${ }^{1, \text { a }}$, Ю. В. Леонтьева ${ }^{2, \text { б }}$ \\ ${ }^{1}$ Байкальский государственный университет. Иркутск, Россия \\ 2 Уральский феедеральный университет, Екатеринбург, Россия \\ a (iD) $\underline{0000-0002-5898-0537}$ \\ ${ }^{\sigma}$ (D) $\underline{0000-0003-4676-9926}$
}

\begin{abstract}
АННОТАЦИЯ
Целью статьи является изучение опыта применения налога с оборота и отчислений от прибыли в Советском Союзе в период с 1926 по 1940 г. Для исследования роли этих налогов в успехах индустриализации советской экономики мы использовали историко-логический метод. Мы анализировали и сравнивали
\end{abstract}


основные показатели, характеризующие развитие экономики и показатели, характеризующие сбор налогов до и после проведения налоговой реформы 1930 г. Мы подтвердили гипотезу о том, что налог с оборота и отчисления от прибыли в условиях регулируемых цен и плановой экономики привели к формированию в СССР модели противозатратной экономики. Мы показали, что эта модель обеспечивала постоянное снижение издержек производства продукции, форсированную урбанизацию населения и беспрецедентные темпы роста тяжелой промышленности. В результате реформы 1930 г. налоговая система была максимально упрощена, что обеспечило достижение значимого фискального эффекта и ряда социальных эффектов. Два введенных специфических налоговых инструмента - налог с оборота и отчисления из прибыли предприятий в условиях плановой экономики позволили мобилизовать огромные ресурсы для инвестиций. Инвестиции обеспечили рост производства в отраслях тяжелой промышленности 10-16 \% в год, что привело к мультипликативному эффекту во всей экономике. Однако мобилизация финансовых ресурсов происходила за счет потребителей, так как повышенными налогами облагались в основном предприятия легкой и пищевой промышленности. Это привело к «товарному голоду», введению продуктовых карточек, жесткому административному управлению. Сделан вывод, что отличительной особенностью проводимой Советским Союзом фискальной политики был ее комплексный характер и подчинение единой ключевой цели индустриализации страны.

\section{КЛЮЧЕВЫЕ СЛОВА}

налог с оборота, отчисления от прибыли, индустриализация, плановая экономика, антизатратная экономика.

\section{Relevance}

Economic growth and technological innovation are the main priorities in the development of Russia. The country's progress in this respect, however, is limited, to say the least. In order to achieve a major technological breakthrough, substantial investment is required, which means that there is a need for efficient instruments of taxation, capable of mobilizing the necessary resources. In this context, it would be interesting to look at the Soviet experience of designing and enforcing its fiscal policy in the 1930s.

The tax reforms of the 1930s were, first and foremost, aimed at creating efficient instruments of taxation to provide sufficient resources for accelerated industrialization. One cannot help but admit that the formula proposed by Soviet finance professionals successfully ensured accelerated urbanization and unprecedented growth of heavy industry during the country's transition to the governmentcontrolled collective economic system.

In the course of the three incomplete five-year-plan periods lasting from 1928 to 1940 , the country built 364 new towns, constructed and put into operation 9,000 large production facilities - which makes an average of two facilities a day! The actual added value in sectors other than agriculture increased by an annual average of $10.4 \%[1 ; 2]$. Within the centralized economic system, the tax policy became an effective instrument of achieving goals and implementing tasks set by the government, which makes it extremely important to study this experience.

During the world economic crisis of 1929-1933, J. M. Keynes [2] proposed a comprehensive concept of economic regulation with a special emphasis on active fiscal policy. Practical implementation of the Keynesian concept enabled market economies to recover from the depression. Meanwhile, the Soviet Union, which had a planned economy and, therefore, completely different economic and political conditions, focused on rapid industrialization. In both market-driven and planned economies, the state and proactive tax policy played a decisive role in this process.

At the same time, the two types of economies used radically different combinations of taxes. J. M. Keynes suggested actively manipulating tax rates and government spending in order to implement discretionary and non-discretionary mon- 
etary policies. Soviet finance professionals, in their turn, designed a brand new formula of a tax reform. They suggested that the diverse taxes paid by enterprises be replaced with two main taxes - the turnover tax and the tax charges on profits. Methodologically, these two different solutions had the same goal -strengthening the role of the state - and brought positive results in the respective types of economy. The legacy of Keynes has been studied fairly well, whereas the Soviet positive taxation experience remains largely underexplored. Meanwhile, the unique nature of the Soviet tax reform in the period of a centrally planned economy is worthy of scholarly attention.

This article aims to study the experience of the Soviet fiscal reform, which included the introduction of the turnover tax and tax charges on profits, and the role of this reform in the success of Soviet industrialization in the 1930s. It should be noted that we are going to focus exclusively on the economic outcomes of the fiscal policy rather than consider its social effects. Our hypothesis is that the turnover tax and tax charges on profits along with the price regulation and planned economy allowed the Soviet government to establish a cost-effective economic model, which involved optimization of production costs, accelerated growth of the urban population and unprecedented expansion of heavy industry.

\section{Literature review}

The analysis of the research literature reveals a certain interest that researchers had in the Soviet tax policy in the industrialization period. There is no, however, uniform opinion among Soviet and Russian economists about the impact of the tax policy on economic growth. As Table 1 illustrates, in different periods researchers focused on different aspects of the problem.

The differences in the scope of these studies can be explained by the differences in the subject matter of the research and the differences in the approaches applied to assess the reform's outcomes. For example, Soviet economists in the 1930s-1960s focused on the mechanism of realizing the tax reform, assessed its progress and challenges [3-13]. In the 1960s-1990s, researchers were more interested in improving the tax system existing at that time. It is worth noting that the works of that period are somewhat biased, which negatively affected their search for solutions to contemporary economic problems.

Post-Soviet studies also differ in their assessment of the role of the tax reforms in the Soviet economic policy. For example, N. P. Figurnova [14], A. I. Kolganov and A. V. Buzgalin [15] view them as a "robbery" that led to the impoverishment of people in rural areas, that is, the majority of the Soviet population. I. V. Karavayeva and V. A. Maltsev [16] view the turnover

\section{Studies of the Soviet tax reform in the industrialization period}

\begin{tabular}{|c|c|c|c|}
\hline & Studies of the 1930s-1960s & Studies of the 1960s-1990s & Post-Soviet studies \\
\hline Authors & $\begin{array}{l}\text { A. M. Alexandrov, } \\
\text { P. V. Mikeladze, } \\
\text { P. I. Polozov, } \\
\text { M. I. Lifshits, } \\
\text { A. A. Sokolov et al. }\end{array}$ & $\begin{array}{l}\text { D. L. Argova, } \\
\text { E. A. Voznesensky, } \\
\text { V. P. Dyachenko, } \\
\text { G. L. Rabinovich, } \\
\text { A. A. Barsov et al. }\end{array}$ & $\begin{array}{l}\text { I. V. Karavayeva } \\
\text { V. A. Maltsev, } \\
\text { N. P. Figurnova, } \\
\text { V. Y. Katasonov, } \\
\text { A. I. Kolganov, } \\
\text { A. V. Buzgalin, } \\
\text { V. M. Pushkareva, } \\
\text { I. A. Mayburov } \\
\text { A. P. Kireenko et al. }\end{array}$ \\
\hline $\begin{array}{l}\text { Focus of } \\
\text { research }\end{array}$ & $\begin{array}{l}\text { Implementation of the tax } \\
\text { reform, its outcomes and its } \\
\text { complications }\end{array}$ & $\begin{array}{l}\text { Improvements to the } \\
\text { existing taxation system }\end{array}$ & $\begin{array}{l}\text { Outcomes of the tax } \\
\text { reform }\end{array}$ \\
\hline Results & $\begin{array}{l}\text { This reform presents a } \\
\text { completely new approach to } \\
\text { taxation based on the principle } \\
\text { of comprehensiveness }\end{array}$ & $\begin{array}{l}\text { Detailed description of the } \\
\text { taxation instruments }\end{array}$ & $\begin{array}{l}\text { Assessment of the } \\
\text { reform's outcomes }\end{array}$ \\
\hline
\end{tabular}


tax as a way of channeling funds from agriculture to manufacturing. V. Y. Katasonov [17] takes a different perspective: he agrees that the turnover tax helped to provide more funding for industrial development and explains the role of this tax in building a cost-effective economy. As for the studies of specific taxation instruments, they tend to analyze the current taxation practices within the framework of Western economic theories [18-22].

Earlier international studies of the Soviet economy suffered from the absence of plausible data and, therefore, were largely critical of the collectivization methods. There is only a handful of studies that take a comprehensive look at the Soviet system of taxation (e.g. R. W. Davies [23; 24] and [23; 25]). J. R. Millar [26], too, argues that industrialization was carried out at the expense of the rural population and the city poor. At the same time, he observes that the taxation system of that period was based on the dominating ideology of planned economy and on fundamental political and cultural concepts.

The authors of more recent works recognize the achievements of the Soviet economy without political bias. They admit that the input data were of insufficient quality and continue to be revised many years on. Moreover, P. Wanless [27] sees it as a mistake to disregard the issue of taxation in Socialist countries, especially the market elements of tax policies.

Some studies also confirm that the Soviet economy was on the rise and the living standards were improving. For example, consumption per capita increased by $21 \%$ between 1928 and 1939 (average annual growth of $1.8 \%$ ), which refutes the assumption that as a result of industrialization, the living standards were sacrificed for the sake of producing ever-growing amounts of steel and armaments. The question is whether there were any alternatives to the socially disastrous collectivization campaign or not. The simulation models constructed by R. C. Allen [28] show that the ultimate results of industrialization could have been achieved if the New Economic Policy had been continued. The models do not specify, however, the sources of man- power. At the same time, Allen admits that the social disaster brought about by collectivization had even worse repercussions for rural-urban migration.

A. A. Barsov [29], J. Millar [30; 31], and M. Ellman [32] established that the net profit was not transferred from agriculture to the rest of the economy, so the capital accrued in agriculture was not the source of investment in manufacturing. The turnover tax on consumer goods (primarily processed agricultural produce) was indeed used to finance growing investment, but in fact consumption was not reduced in order to obtain investment resources. Investment grew due to the mobilization of workers, who would otherwise have remained unemployed. Part of the workforce was used to expand the production of capital goods (known as Group A industry) and boost investment growth. The government procurement system sped up the process, thus decreasing consumption in rural areas as compared to cities and increasing rural-urban migration as a result. Allen [28] names two defining factors of the success of industrialization: an investment strategy that prioritized heavy industry and a combination of high industrial output targets and not-so-rigid budgetary constraints.

The success of industrialization impressed many Western experts. According to S. Wheatcroft [33], the Soviet industrial output grew 2.5-3.5-fold between 1928 and 1937 (an average annual growth of 10.5 to $16 \%$ ). Harrisson, however, notes that the official Soviet statistics exaggerated the long-run economic growth, pointing out that the labor productivity indicators should be taken with a grain of salt [34].

\section{Analysis of budgetary and tax reforms in the USSR in 1928-1937}

Both the fiscal policy and the instruments to implement it were developed by Soviet economists. These instruments were adjusted to maximize the results of the tax reform. In December 1925, the Soviet government set the task to "ensure industrialization" of the country and in 1928, the first five-year-plan was launched. The 
plan envisaged the construction of several dozen modern heavy industry "giants" [30]. It was necessary to ensure an accelerated growth in Group A output (capital goods) in comparison to Group B production (consumer goods), which brought to the forefront the problem of funding.

Specific characteristics of budgetary and taxation instruments were determined by the general operational peculiarities of the Soviet economy (Figure 1).

As a result, the Soviet planned economy functioned as a single mechanism operated from the center, "manually" or "automatically", mainly through prices and mandatory levies on enterprises, including taxes.

In the brief preparatory period before the reform in 1926-1928, the amount and sources of the required resources were determined. Despite an increase in industry savings (accumulated depreciation and profits increased by nearly 60\% from 1925 till 1928), it was not enough. As a result, to fund industrialization, it was decided to use the funds accumulated in other industries and by people. It was also stipulated that the search for sources of savings should be accompanied by the all-round production cost cutting measures. As a result, in 1926 around 1billion roubles was invested in the manufacturing industry, which meant a $150 \%$ increase in comparison with the previous year. In 1926-1928, the number of large production facilities doubled, while the gross output grew by 132\% in comparison with 1913.

In 1930-1932, the new ideological base was used as a foundation for a com- prehensive reform of the budgetary and tax systems and credit relations existing at that time. The reform aimed to create a mechanism that would help increase industrial savings by promoting self-financing (khozraschet) and by incentivizing enterprises economically. The budgetary and tax reform led to the creation of a costeffective economy. Other results of the reform include the following:

- a steady growth in public revenue;

- uninterrupted and systematic revenue dynamics;

- cutting production costs cost;

- a steady growth in labor productivity; dards.

- improvement in the living stan-

The reform was based on a comprehensive approach and covered the system of settlements, lending, government expenditures, insurance, taxes and compulsory levies on individuals [35]. Taxation instruments and other compulsory charges paid by enterprises were at the core of the new state financing mechanism. The new taxation system was built upon the following premises:

1. The means of production, material and supplies were publicly owned.

2. Administration methods in the national economy combined directive planning of all the key targets and selffinancing (commercial financing). The latter policy was enforced by incentivizing companies economically.

3. Pricing targets, production cost targets and profit targets were mandatory (set through directives) for enterprises.

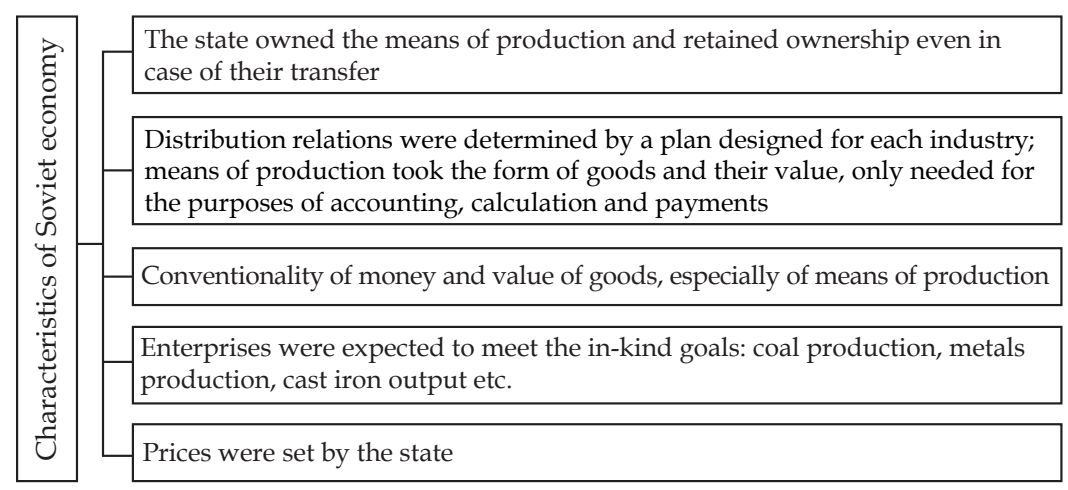

Figure 1. Characteristics of the planned economy in the USSR 
4. Rigid distribution of resources and manufactured products was controlled from the single government center.

5. Revenues were to be remitted to the state budget on a regular basis and in sufficient amounts.

6. Permanent financial control over the fulfillment of the plan and financial and budgetary discipline was to be executed.

The enforcement of the new principles required both rigid command methods and indirect instruments such as the new taxation mechanism of generating public revenue for its further distribution. The key instruments of the mechanism were tax charges on corporate income and the turnover tax that was levied as a percentage of the product price. The tax was to be remitted to the state regardless of the enterprise's performance.

The new taxation mechanism was the product of the radical tax reform of 1930 . As a result of the reform, the tax system was simplified to the maximum: the system of excise taxes was practically abolished; the diversity of corporate taxes was reduced to the two main levies - the turnover tax and tax charges on profits.

The turnover tax replaced 53 taxes and non-tax payments, including trade tax, practically all local taxes and charges. The tax was computed using the difference method on the basis of fixed prices of goods turned out by different industries. In general, the Soviet understanding of tax was different from the understanding of tax in a market economy. The main feature of the turnover tax is a variety of tax rates: in 1933, there were over 400 tax rates; in 1937, 1,109; taking into consideration the regional differences in food prices, 2,444. The tax was only simplified somewhat during the pre-war period: the number of rates was reduced; the difference method was abolished for a number of industrial goods [36].

Charges on profits replaced five other taxes, including the corporate income tax paid by state-owned companies and the excess profits tax. Essentially, this meant direct extraction of the larger portion of profit into the budget. Tax charges on profits were even less in line with the accepted market model of computing corporation tax and, consequently, had a quasitax nature.

The turnover tax and charges on profit created an effective system of total control over enterprises' operations, motivating them to keep cutting their production costs.

Pricing issues were considered crucial in the Soviet fiscal policy. Prices were set by the planning agency and were used for accounting, computing and settlement purposes. The Soviet state used the pricing policy for such critical economic functions as distribution and utilization of the national income, promoting the circulation of commodities and so on.

The wholesale price in heavy industry ("production of the means of production") was the price at which products were distributed among state-owned companies under the material and supplies plan. The cost-based approach was at the core of price planning, that is, the price was set at the level equal to the cost of production plus planned profit (the company's net income) that was calculated on the basis of the industry's planned profitability. The cost of production was assumed to be an industrywide average including the performance of the leading enterprises. Differences in planned profitability by industry corresponded to the differences in the speed of fixed assets renewal, their structure and the periods of working capital turnover.

Financial performance of companies was measured as the difference between the government-fixed product prices and the cost of manufacturing these products with the turnover tax. If a company exceeded the target cost of production, it would not meet its earnings target; if it managed to reduce the cost of production to the level below planned, it would have excess earnings. As the company had no say in the statutorily set prices, its earnings, the rate of the turnover tax and the output volume were entirely a function of the cost of production. Consequently, cost cutting was of critical importance for the growth in earnings and it was the sole factor influencing earnings and the fulfillment of the profit plan. 
Enterprises usually retained their profits to use them for a planned increase in fixed investments. Profits in excess of fixed investments were extracted into the state budget as charges on profit. The remaining part of the "excess profit" was spent on welfare support for the staff. If a company did not have enough profits to increase its working capital and fixed investment, the shortfall was covered by the government. The amount of public funding to be received by the company was computed on the basis of planned earnings. A failure to meet the profit accumulation target placed the company in a tense financial position.

In some cases, the cost of production was planned at a level higher than producer prices (which meant the company operated at a planned loss). As a result, companies turning out such products could not fully recover their production costs by selling them. The resulting shortfall was covered with government-provided subsidies [37].

The state was therefore able to build a mechanism of resource re-distribution among industries while executing full administrative control over the operations of enterprises. The key instruments of such resource redistribution were the turnover tax and tax charges of profits.

\section{Specific mechanism of tax charges on profits}

Tax charges on profits were introduced in 1930 by the Statute on Taxing Profits of State-Owned Enterprises ${ }^{1}$. The statute defined the following features of these tax charges. First, the tax was computed and paid in a decentralized way companies were in charge of computing, accounting and paying the tax on all kinds of planned profits. Second, the tax rates were differentiated by industry and revised annually, varying from 10 to $85 \%$ of profits. If the planned profit exceeded fixed investments (including an increase in working capital), a higher tax rate was applied. However, a small share of profits

${ }^{1}$ Decree on the deduction to the state income of state-owned enterprises. The collection of laws of the USSR. 1930, no. 46, art. 478. (In Russ.) retained by companies could be viewed as an economic incentive for development.

Third, the estimated tax was initially remitted on a monthly basis at a rate of $85 \%$ of the planned profit, with a refund adjusted for the actual profit at the end of the year. Since 1932, the tax was to be paid on a quarterly basis, with payments due calculated using income statements and a tax adjustment at the end of the year.

Fourth, the tax was remitted to appropriate administrations depending on the company's subordination: to the national budget if the company had a national status; to republican and local budgets if the company was of republican or local significance.

\section{Specific mechanism of the turnover tax}

The Statute on the Turnover Tax ${ }^{2}$ set the following principles for calculating the turnover tax and remitting it to the state.

First, the turnover tax was collected when a product was sold by industrial associations, state-owned companies that were not part of the associations, and cooperatives. Government-set prices for manufactured goods remained unchanged regardless of the number of links in the supply chain that the goods passed through before reaching the consumer. The principle had to do with the nature of the turnover tax as the centralized net income of the state. The net income of society, for its part, could only increase through the expansion of production and higher labor productivity in manufacturing sectors.

Second, the turnover tax was imposed only once in the chain of sales. If companies handed over products to associations, transactions between them were exempted from the turnover tax. Cooperatives, too, were exempt from the turnover tax if they sold their products to superior organizations or organizations of the same status. The tax was paid again if a product was reworked or subjected to production operations that increased its value. The

${ }^{2}$ Regulation on the turnover tax of enterprises of the socialized sector. The collection of laws of the USSR. 1930, no. 46, art. 477. (In Russ.) 
statute stipulated that packaging, cutting, wrapping and packing operations should not increase the selling price and levying the tax as they did not require a lot of manpower and did not significantly affect the properties of the product.

Third, the turnover tax was used as an instrument for cross-industrial redistribution of resources. For example, companies that produced or extracted critical raw materials (ores, flax, hemp, cotton, wool, seeds etc.) were exempt from the turnover tax. Companies producing agricultural equipment and tools, construction machinery, printing companies, bakeries, electricity companies and some other producers did not pay it either. At the same time, clothing and textiles and a number of other consumer goods, e.g. chocolate, butter, watches, cameras, were taxed at a higher rate. Different tax rates helped the government ensure a degree of profitability for goods and companies that promoted khozraschet (self-financing).

Fourth, the turnover tax was paid in a decentralized way; the amount of tax to be paid was computed by the company considering its actual sales (on each sales transaction, with bills submitted to the state bank, Gosbank). On the one hand, such frequency of tax payments ensured regular tax receipts for the government. On the other hand, financial resources were extracted from enterprises, which encouraged them to speed up the cash cycle and increase the company's own savings.

Fifth, the tax revenue was shared among the government levels. The tax was originally remitted to the national budget, which discouraged the local financial authorities from administering it effectively.
Subsequently, the tax revenue was split among the republican and local budgets, making them more financially sustainable and improving financial control locally.

\section{Taxation system as an incentive for cutting production costs}

The 1930 tax reform established in the USSR a simple and fairly rigid tax system aimed at encouraging cost cutting in production (see Figure 2).

Sources of investment funds were public funds (national budget) as well as companies' own funds (a share of profits). Government-provided funds, which played a decisive role, enabled the authorities to redistribute sources of fixed investments among industries and territories. The national budget was replenished through the turnover tax and tax charges on profits. The levies made it possible to efficiently extract a large share of companies' financial resources into the budget and encouraged companies to reduce their cost of production. A low turnover tax rate and a company's own efficient performance resulted in growing profits and charges on profits, thus ensuring considerable amounts of the company's own sources of fixed investment funds and receipts for the state. A higher turnover tax rate was expected to drive the transfer of the resources to the national budget, leading to lower profits and tax charges on profits and thus stimulating cost cutting.

As a result, all companies regardless of their performance contributed to the savings fund. Planned prices were set on the basis of the average production cost in the industry, with the achievements of leading companies taken into consideration.

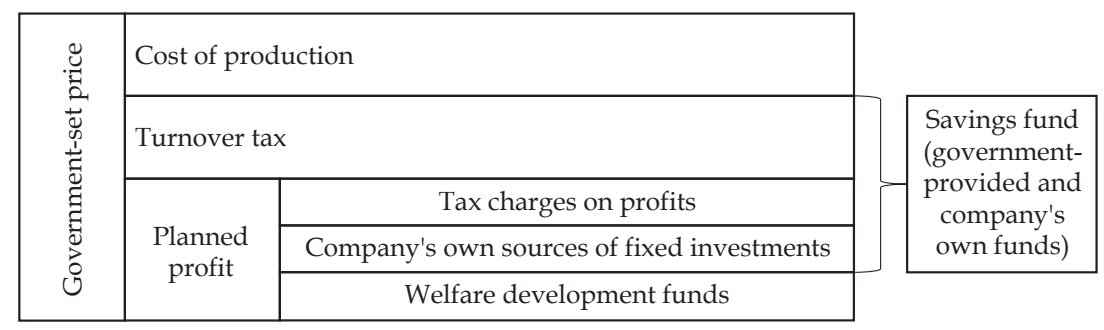

Figure 2. Relationships between the main economic parameters of companies' performance and sources of fixed investments 
At the initial stage of the reforms, a considerable number of industrial companies were planned as loss-making ones. They received subsidies from the state while paying the turnover tax, which resulted in an insignificant share of profits in the net income of state-owned manufacturing companies and the dominant role of the turnover tax in generating public revenue. In that period, the turnover tax constituted both a part of the public net income and the share of the total social product that was utilized for covering production costs in heavy industry. In later years, when significant advances were made in reducing production costs and increasing profitability, profits started to grow faster than proceeds from the turnover tax and the revenue from profit charges started to dominate the budget.

\section{Outcomes of the budgetary and tax reforms}

As a result of the 1930 reforms, in the USSR, a unique fiscal mechanism was created that proved to be effective later, during World War 2. The alignment of the tax and budgetary policies enabled the country to implement its ambitious industrialization plan. The results of the tax revenue reform are summarized in Table 2.

The increase in government revenues and a practically proportional growth of

Basic parameters of the Soviet state budget in 1928-1940, billion roubles/\%

Table 2

\begin{tabular}{|c|c|c|c|c|c|c|c|}
\hline \multirow[t]{2}{*}{ Indicator } & \multirow[t]{2}{*}{ 1928/1929* } & \multirow[t]{2}{*}{1932} & \multirow[t]{2}{*}{1937} & \multirow[t]{2}{*}{1940} & \multicolumn{3}{|c|}{ Growth rate } \\
\hline & & & & & $\begin{array}{c}1932 / \\
1928-1929\end{array}$ & $1937 / 1932$ & 1940/1937 \\
\hline Public revenues & $\begin{array}{l}8.8 \\
100\end{array}$ & $\frac{38.0}{100}$ & $\frac{109.3}{100}$ & $\frac{180.2}{100}$ & 4.3 & 2.9 & 1.7 \\
\hline including & & & & & & & \\
\hline Turnover tax & $\frac{3.1 * *}{35.5}$ & $\frac{19.6}{51.5}$ & $\frac{75.9}{69.4}$ & $\frac{105.9}{58.7}$ & 6.3 & 3.9 & 1.4 \\
\hline heavy industry & $n / a^{* * *}$ & $\frac{1.4}{3.6}$ & $\frac{8.2}{7.5}$ & $\frac{10.7}{5.9}$ & - & 5.9 & 1.3 \\
\hline textiles and clothing & $n / a$ & $\frac{3.6}{9.6}$ & $\frac{8.9}{8.1}$ & $\frac{16.0}{8.9}$ & - & 2.5 & 1.8 \\
\hline food industry & $n / a$ & $\frac{9.6}{25.3}$ & $\frac{25.3}{23.1}$ & $\frac{41.7}{23.1}$ & - & 2.6 & 1.6 \\
\hline Tax charges on profits & $\frac{1.4}{15.9}$ & $\frac{5.0}{13.2}$ & $\frac{9.3}{8.5}$ & $\frac{21.7}{12.1}$ & 3.6 & 1.9 & 2.3 \\
\hline heavy industry & $\frac{0.1}{1.1}$ & $\frac{0.4}{1.1}$ & $\frac{1.5}{1.4}$ & $\frac{1.7}{0.9}$ & 4 & 3.75 & 1.1 \\
\hline textiles and clothing & $\frac{0.1}{1.1}$ & $\frac{0.2}{0.5}$ & $\frac{1.0}{0.9}$ & $\frac{4.7}{2.6}$ & 2 & 5 & 4.7 \\
\hline food industry & $\frac{0.01 /}{0.1}$ & $\frac{0.2 /}{0.5}$ & $\frac{1.5 /}{1.4}$ & $\frac{6.0 /}{3.3}$ & 20 & 7.5 & 4 \\
\hline Public spending & $\frac{8.8}{100}$ & $\frac{38.0}{100}$ & $\frac{106.2}{100}$ & $\frac{174.4}{100}$ & 4.3 & 2.8 & 1.6 \\
\hline financing of industry & $\frac{1.2}{13.6}$ & $\frac{13.3}{35.0}$ & $\frac{16.7}{15.7}$ & $\mathrm{n} / \mathrm{a}$ & 11.1 & 1.3 & - \\
\hline heavy industry & $\frac{0.8 /}{9.1}$ & $\frac{11.6 /}{30.5}$ & $\frac{12.7 /}{12.0}$ & $\frac{19.4 /}{11.1}$ & 14.5 & 1.1 & 1.5 \\
\hline textiles and clothing & $\frac{0.03}{0.3}$ & $\frac{0.4}{1.1}$ & $\frac{2.0}{1.9}$ & $\frac{0.7}{0.4}$ & 13.3 & 5 & 0.35 \\
\hline food industry & $\frac{0.02}{0.2}$ & $\frac{0.5}{1.3}$ & $\frac{1.1}{1.0}$ & $\frac{1.5}{0.9}$ & 25 & 2.2 & 1.4 \\
\hline
\end{tabular}

* Before 1930, the financial year in the USSR started on 1 October and ended on 30 September;

** Denotes the sum total of the corresponding revenues that in 1930 were consolidated into the turnover tax;

*** The data are not available.

Source: [38]. 
expenditures was achieved through increasing turnover tax receipts, while tax charges on profits were much less significant. It should be noted that financial resources were redistributed by the central administrative unit through the fiscal mechanism. For example, the share of the turnover tax extracted from the textiles and clothing sector and food companies made up nearly $35 \%$ of the tax revenue, while heavy industry accounted for less than $4 \%$. Despite significant investments and heavy industry expansion in the first five-year periods, there were no drastic changes to the structure of turnover tax receipts. At the same time, profits made by heavy industry enterprises were comparable to profitsin other industries and sometimes even exceeded them. The government thus not only subsidized such companies, but also provided them with extra resources so that companies could invest their own savings (Figure 3).

The analysis of public spending shows that expenditures on heavy industry enterprises increased at an accelerated pace. As a result, investments in the production of the means of production doubled. The larger share of funds was invested by the state in the production of Group A goods (means of production), which were then distributed among enterprises (Table 3).

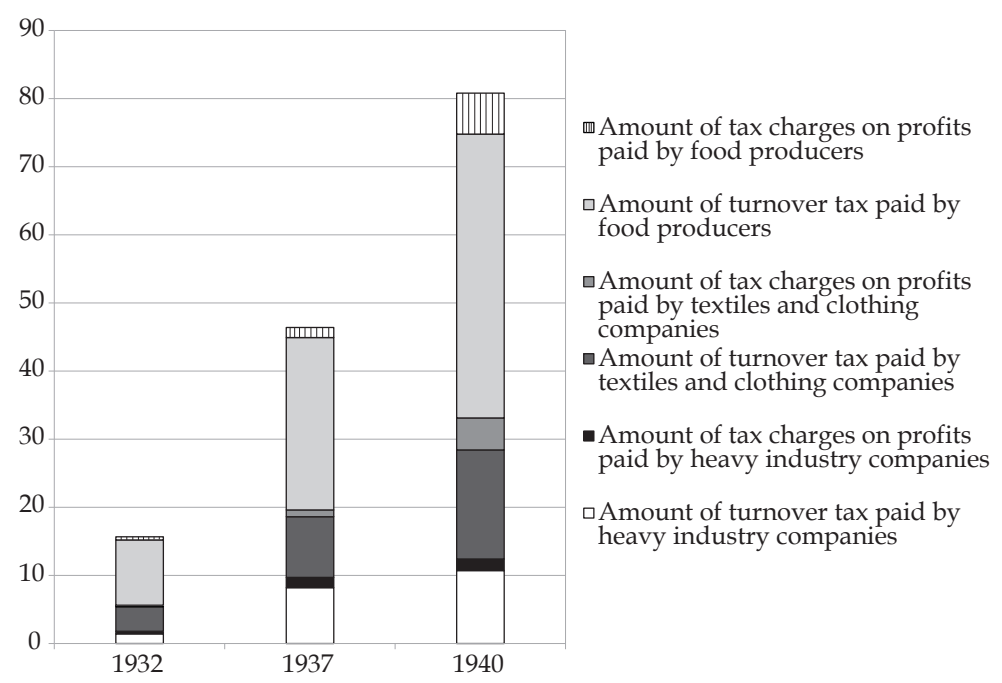

Figure 3. Structure of the tax revenue in the USSR

Table 3

Capital investment in industrial construction in 1928-1940 and its outcomes

\begin{tabular}{|l|c|c|c|c|c|}
\hline & 1928/29-1932 & $\mathbf{1 9 3 3 - 1 9 3 7}$ & $\begin{array}{c}\text { 1938-1942 } \\
\text { (plan) }\end{array}$ & \multicolumn{2}{|c|}{ Growth rate } \\
\hline $\begin{array}{l}\text { Total fixed investments in indus- } \\
\text { trial construction, billion roubles / }\end{array}$ & $\underline{24.8}$ & $\frac{58.6}{100}$ & $\underline{111.9}$ & 2.36 & 4.51 \\
\hline including investments in: & & & & & \\
\hline production of means of production & $\underline{21.3}$ & $\underline{49.8}$ & $\underline{93.9}$ & 2.3 & 4.4 \\
\hline production of consumer goods & $\underline{3.5}$ & $\underline{8.8}$ & $\underline{18.0}$ & 2.5 & 5.1 \\
\hline $\begin{array}{l}\text { For reference: Effects of capital } \\
\text { investment: }\end{array}$ & 1928 & 1932 & 1937 & 1940 & $1940 / 1928$ \\
\hline $\begin{array}{l}\text { Gross output in comparable prices, } \\
\text { billion roubles }\end{array}$ & 21.4 & 43.3 & 95.5 & 138.5 & 6.47 \\
\hline Share of manufacturing in GDP, \% & & & & & \\
\hline Means of production & 39.5 & 53.4 & 57.8 & 61.2 & +21.7 П.П \\
\hline Consumer goods & 60.5 & 46.6 & 42.2 & 38.8 & -21.7 П.П. \\
\hline
\end{tabular}

Source: [39; 40] 
The battle for industrialization brought about some major successes. In 1929, the industrial output was nearly twice the level of 1913 before Word War 1. The share of industrial production in GDP increased from $42.1 \%$ in 1913 to $54.5 \%$ in 1929. Annual GDP growth between 1928 and 1940 was around $4.6 \%$ (according to earlier estimates, 3 to $6.3 \%$ ) [41; 42].

The redistribution of financial resources and accelerated expansion of industry led to the redistribution of human resources and a higher employment rate, which, in addition to the economic effect, had a major social impact. The construction of large manufacturing companies spurred the construction of urban agglomerations: the number of newly emerging cities and towns in that period exceeded 300. Higher population density in those areas made health care and education more accessible. For example, in 1928 , the share of the urban population in the USSR was only $18 \%$. By 1940 , over $50 \%$ of the Soviet population were living in cities, and the number of people with university degrees grew 3.9 times.

Stimulation of enterprises to cut their production costs resulted in the growth of average wages and increased productivity. Per capita consumption in 1938 was higher by $22 \%$ than in 1928 .

\section{Conclusions}

The Soviet fiscal policy of 1928-1937, which had a comprehensive character, proved to be a highly effective instrument for achieving industrialization goals. Within this policy, all elements of taxation and budgeting were oriented towards one major goal. It should be noted that in that period the instruments of direct command planning played a significant role in economic administration. It was, however, the use of taxation and budgetary instruments that made the fiscal policy efficient.
The system of direct planning used key performance indicators to measure the efficiency of industrial enterprises while the use of the turnover tax and tax charges on profits made it possible to mobilize financial resources of all industries and redirect them to one savings fund. The fund served as a source of investment, ensuring a high pace of economic growth and turning the country into an industrial power with advanced technological fixed capital assets. An important outcome of the 1930 fiscal reform was that enterprises became more focused on cost cutting and on increasing their labor productivity. The redistribution of financial resources and accelerated industrial growth led to the redistribution of human resources and increased employment rate.

The Soviet economic policy was not, of course, devoid of drawbacks. At the initial stage, financial resources were mobilized at the expense of end consumers, which means that the textiles and clothing sector and the food production sector had to bear a higher tax burden, which resulted in product shortages and high retail prices and thus required direct administrative distribution of staple goods (rationing). It was impossible to implement such a policy without rigid administrative control. Nevertheless, the economic growth in heavy industry reached $10-16 \%$ a year at the beginning of industrialization and had a multiplicative effect on the entire economy.

The desired effect was achieved really fast, but the fiscal reform also had its darker side as the mobilization of resources often happened to the detriment of customers. The tasks and goals of the economic policy should have been adjusted more frequently by taking into consideration social well-being and the needs of the consumer goods sector.

\section{References}

1. Allen R. C. Capital Accumulation, the Soft Budget Constraint and Soviet Industrialization. Vancouver: B.C. Canada, Department of Economics University of British Columbia; 1997.

2. Keynes J. M. The General Theory of Employment, Interest and Money. London: Macmillan; 1936.

3. Anchishkin A. I. Turnover tax - a specific form of the surplus product of socialist production. Moscow: Vysshaya shkola; 1962. (In Russ.) 
4. Argova D. L. Turnover tax rates: a practical guide. Moscow: Finansy i statistika; 1983. (In Russ.)

5. Bachurin A. V. Profit and turnover tax in the USSR. Moscow: Gosfinizdat; 1955. (In Russ.)

6. Bryukhanov N. P. Budget, finance, economy of the USSR in 1926-27. Moscow: Finizdat NKF SSSR; 1927. (In Russ.)

7. Voznesenskiy N. The Soviet military economy during the Patriotic War. Moscow: Gospolitizdat; 1948. (In Russ.)

8. Kovylin V. A. Turnover tax. Moscow: Gosfinizdat; 1946. (In Russ.)

9. Kutler K. N. State revenues of the USSR: collection technology. Moscow: Gosfinizdat; 1940. (In Russ.)

10. Lavrov V. V. The budget of the country of socialism. Moscow: Gosfinizdat; 1950. (In Russ.)

11. Lifshits M. I. Reconstruction of the withdrawal system from the socialized sector. Finansovyye problemy planovogo khozyaystva $=$ Financial problems of a planned economy . 1930;(5):288-397. (In Russ.)

12. Mariyakhin G. L. The budget and national policy of the USSR. Moscow: Gosfinizdat; 1938. (In Russ.)

13. Malafeyev A. N. History of pricing in the USSR: 1917-1963. Moscow: Mysl; 1964. (In Russ.)

14. Figurnova N. P. Stalin's model of development and society's hopes for Russia's rebirth.

Ekonomicheskaya nauka sovremennoy Rossii = Economic science of modern Russia. 2001;(3):137-148. (In Russ.)

15. Buzgalin A. V., Kolganov A. I. 10 myths about the USSR. Moscow: Yauza Eksmo; 2010. (In Russ.)

16. Karavayeva I. V., Maltsev V. A. The priorities of fiscal policy in the period of industrial transformations of 1920-1930s. Finansy i kredit = Finance and Credit. 2008;(15):67-75. (In Russ.)

17. Katasonov V. Yu. Stalin's economy. Moscow: Institut russkoy tsivilizatsii; 2014. (In Russ.)

18. Orlova E. N. Tax evasion and its impact on the realization of the tax potential of households. Nalogi i finansovoye parvo = Taxes and Financial Law. 2012;(9):193-198. (In Russ.)

19. Kireenko A. P., Fedotov D. Yu. (eds) The shadow economy and tax evasion. Irkutsk: Irkutsk State Transport University; 2017. (In Russ.)

20. Fedotov D. Yu., Nevzorova E. N., Orlova E. N. A tax method to calculate the value of the shadow economy of Russian regions. Regionalnaya ekonomika: teoriya $i$ praktika $=$ Regional Economy: Theory and Practice. 2017;15(11):2015-2032. (In Russ.) DOI: 10.24891/re.15.1 1.2015

21. Fedotov D. Yu. Corruption and tax evasion: the interrelation of social phenomena. Finansy $i$ kredit = Finance and Credit. 2018;24(12):2849-2862. (In Russ.)

22. Fedotov D. Yu. Analysis of tax revenue forecasting of the federal budget of Russia. Bukhgalterskiy uchet $v$ byudzhetnykh i nekommercheskikh organizatsiyakh = Accounting in Budget and Non-Profit Organizations. 2018;(4):23-36. (In Russ.)

23. Davies R.W. Crisis and Progress in the Soviet Economy. 1931-1933. The Industrialisation of Soviet Russia. London: Macmillan; 1996.

24. Mishustin D. D. Foreign trade and industrialization in the USSR. Moscow: Mezhdunarodnaya kniga; 1938. (In Russ.)

25. Harrison M., Davis R. W. The Soviet Military-Economic Effort during the Second FiveYear Plan (1933-1937). Europe-Asia Studies. 1997;49(3):369-406.

26. Millar J. R., Bahry D. Financing development and tax structure change in the USSR. Faculty Working Papers. 1997;(363):97.

27. Wanless P. Taxation in Centrally Planned Economies. London: Routledge; 1985.

28. Allen R. C. Farm to Factory. A Reinterpretation of the Soviet Industrial Revolution. Princeton: Princeton University Press; 2003.

29. Barsov A. A. Balance of cost exchanges between town and country. Moscow: Nauka; 1969. (In Russ.)

30. Millar J. Soviet Rapid Development and the Agricultural Surplus Hypothesis. Soviet Studies. 1970;22:77-93.

31. Millar J. Mass Collectivization and the Contribution of Soviet Agriculture to the First Five-Year Plan: A Review Article. Slavic Review. 1974;33(4):750-766.

32. Ellman M. Did the Agricultural Surplus Provide the Resources for the Increase in Investment in the USSR During the First Five Year Plan? Economic Journal. 1975;85:844-863.

33. Wheatcroft S. G., Davies R. W., Cooper J. M. Soviet Industrialization Reconsidered: Some Preliminary Conclusions about Economic Development between 1926 and 1941. Economic History Review. 1986;39(2):264-294.

34. Harrison M. Trends in Soviet Labour Productivity, 1928-1985: War, Postwar Recovery, and Slowdown. European Review of Economic History. 1998;2(2):171-200. 
35. Bogachevskiy M. USSR tax system. Moscow: Gosfinizdat; 1938. (In Russ.)

36. Mayburov I. Marking the Centenary of Income Tax in Russia: Theoretical Analysis of Key Stages of the Reform. Journal of Tax Reform. 2015;1(2-3):161-176. DOI: 10.15826/jtr.2015.1.2.010

37. Mayzenberg L. Pricing in national economy of the USSR. Moscow: Gosudarstvennoye izdatelstvo politicheskoy literatury; 1953. (In Russ.)

38. State budget of the USSR. Statistical yearbook. Moscow: ROSPEN; 1955. (In Russ.)

39. History of the Ministry of Finance of Russia. Vol. 3. Moscow: INFRA-M; 2002. (In Russ.)

40. The USSR is a country of socialism (Statistical collection). Moscow: TSUNKHU Gosplana SSSR i V/O Soyuzorguchet; 1936. (In Russ.)

41. Melyantsev V. A. Russia for three centuries: economic growth in a global context. Obshchestvennyye nauki i sovremennost = Social Sciences and Modernity. 2003;(5):84-95. (In Russ.)

42. Mikeladze P. V. Problems of reconstruction of the tax system. Vestnik finansov = Bulletin of Finance. 1929;(9):3-12. (In Russ.)

\section{Acknowledgment}

The work was supported by the Russian Foundation for Basic Research, contract No. 19-010-00365 A.

\section{Authors}

Svetlana K. Sodnomova - PhD in Economics, Associate Professor, Department of Accounting and Taxation, Baikal State University (11 Lenin St., Irkutsk, 664003, Russian Federation); (D) 0000-0002-5898-0537; e-mail: sodnomovask@mail.ru.

Yulia V. Leontyeva - PhD in Economics, Associate Professor, Department of Financial and Tax Management, Ural Federal University (19 Mira St., Ekaterinburg, 620002, Russian Federation); (D 0000-0003-4676-9926; e-mail: uv.leonteva@mail.ru.

\section{For citation}

Sodnomova S. K., Leontyeva Yu. V. Fiscal policy and incentives for development of the Soviet planned economy in the industrialization period. Journal of Tax Reform. 2019;5(1):70-82. DOI: 10.15826/jtr.2019.5.1.061

\section{Article info}

Received December 20, 2018; accepted March 25, 2019

\section{Благодарности}

Статья подготовлена при финансовой поддержке РФФИ, грант № 19-01000365A

\section{Информация об авторах}

Содномова Светлана Константиновна - кандидат экономических наук, доцент, кафедра бухгалтерского учета и налогообложения, Байкальский государственный университет, Иркутск, Россия (Россия, 664003, г. Иркутск, ул. Ленина, 11); (DD 0000-0002-5898-0537; e-mail: sodnomovask@mail.ru.

Леонтьева Юлия Владимировна - кандидат экономических наук, доцент, кафедра финансового и налогового менеджмента, Уральский федеральный университет, Екатеринбург, Россия (Россия, 620002, г. Екатеринбург, ул. Мира, 19); (D) 0000-0003-4676-9926; e-mail: uv.leonteva@mail.ru.

\section{Аля цитирования}

Содномова С. К., Леонтьева Ю. В. Практика использования специфических налоговых инструментов в период индустриализации плановой экономики СССР // Journal of Tax Reform. 2019. T. 5, № 1. C. 70-82. DOI: 10.15826/ jtr.2019.5.1.061

\section{Информация о статье}

Дата поступления 20 декабря 2018 г.; дата принятия к печати 25 марта 2019 г. 